\title{
Penile Cancer pN3 TNM Finding v8
}

National Cancer Institute

\section{Source}

National Cancer Institute. Penile Cancer pN3 TNM Finding v8. NCI Thesaurus. Code C140074.

Penile cancer with extranodal extension of lymph node metastases or pelvic lymph node metastases. (from AJCC 8th Ed.) 